\title{
Effect of Variety Selection on Growth,Development and Yield of White Yam in Southwestern Nigeria
}

\author{
Eruola A. O. ${ }^{1, *}$, Bello N. J. ${ }^{1}$, Ufoegbune G. C. ${ }^{1}$, Makinde A. A. ${ }^{2}$ \\ ${ }^{1}$ University of Agriculture, Abeokuta, Nigeria \\ ${ }^{2}$ National Horticultural Research Institute, Nigeria
}

\begin{abstract}
An on-farm yam experiment was conducted to confirm the agro-climatic potential of Abeokuta, South-western Nigeria for three white yam varieties (Dioscorea rotundata). Three varieties of yam (Efuru, Ise-osi and Oniyere) was selected and related to crop growth and yield. The experiment was laid out in randomized complete block design in three replicate. The result showed that all yam varieties evaluated were suitable for planting in the area. However, Efuru and Ise-osi synchronized perfectly with the pattern of Actual Water Availability and produced good vegetative growth with Leaf Area Index LAI, of 1.08 and 0.91 thereby leading to high tuber yield of 12 tonnes ha ${ }^{-1}$ and 11.64 tonnes ha ${ }^{-1}$, respectively. Oniyere had LAI of 0.44 resulting in a lower tuber yield of 11.53 tonnes ha ${ }^{-1}$.
\end{abstract}

Keywords Dioscorea Rotundata, Variety, Effective Water Availability, Temperatue

\section{Introduction}

Crop production in the tropics as in other parts of the world is sensitive to environmental factors[8]. However, according to[15], climatic factor appeared to be more marked both in terms of its variation over space and time than the other requirements. In particular, climate has both direct and indirect effect on crop production. The direct effect is manifested by the effect of climatic factor on the other components of the plant environment[3][10][6]. Climate determines the nature of the soils, the crops that can be grown, and the type of farming that can be practiced in any region among others[8]. Generally, the major climatic parameters involved in crop production are rainfall, temperature, light, and photoperiod[12][4]. Although soil and thermal factors are not constraints in the study area and the duration of rain is within the range of optimum annual rainfall $(1000-1500 \mathrm{~mm})$ reported for yam growth[7][13][11][5]. It is not enough criteria for suitable crop variety selection in the study area. Selection of a specific variety will have a large impact on the way in which planting date should be managed. Similarly, the time frame in which a crop can be planted due to weather and/or other circumstances should have a large impact on the selection of a suitable variety. Hence, for successful cropping, it is pertinent to identify the characteristic of variety and then synchronize the crop growth cycle with the period of effective water availability

* Corresponding author:

layosky@yahoo.com (Eruola, A. O.)

Published online at http://journal.sapub.org/ijaf

Copyright (C) 2012 Scientific \& Academic Publishing. All Rights Reserved particularly because the rainfall in the area is characterized by an unpredictable distribution, variability and seasonality. The selection of cultivar (variety) has been noted to be among the factor that contributes to the realization of a successful cropping[1][2][9]. This study intend therefore to confirm the agro-climatic potential of the study area for three white yam varieties in order to determine the appropriate variety that will synchronize the crop growth cycle with period of effective water availability.

\section{Materials and Methods}

\subsection{Description of Study Area}

The research was conducted at the Teaching and Research farm of University of Agriculture along Alabata road, Abeokuta $\left(7^{\circ} 15^{\prime} \mathrm{N}, 3^{\circ} 25^{\prime} \mathrm{E}\right)$ in Odeda Local Government Area of Ogun State, South Western Nigeria (fig. 1) during the 2007 and 2008 cropping seasons. The study area is characterized by a tropical climate with distinct wet and dry seasons with bimodal rainfall pattern and mean annual air temperature of about $30^{\circ} \mathrm{C}$. The actual rainfall totals during the 2007 and 2008 cropping season were 1177.2 and $1201.6 \mathrm{~mm}$, respectively. The region is characterized by relatively high temperature with mean annual air temperature being about $30^{\circ} \mathrm{C}$.

The soil at the experimental site was categorized as a well-drained tropical ferruginous soil. The A horizon of the soil is an Oxic Paleudulf of the Iwo series with $83 \%$ sand, 5\% silt and $12 \%$ clay with a pH of 6 considered tolerable by yam cultivation[9]. 


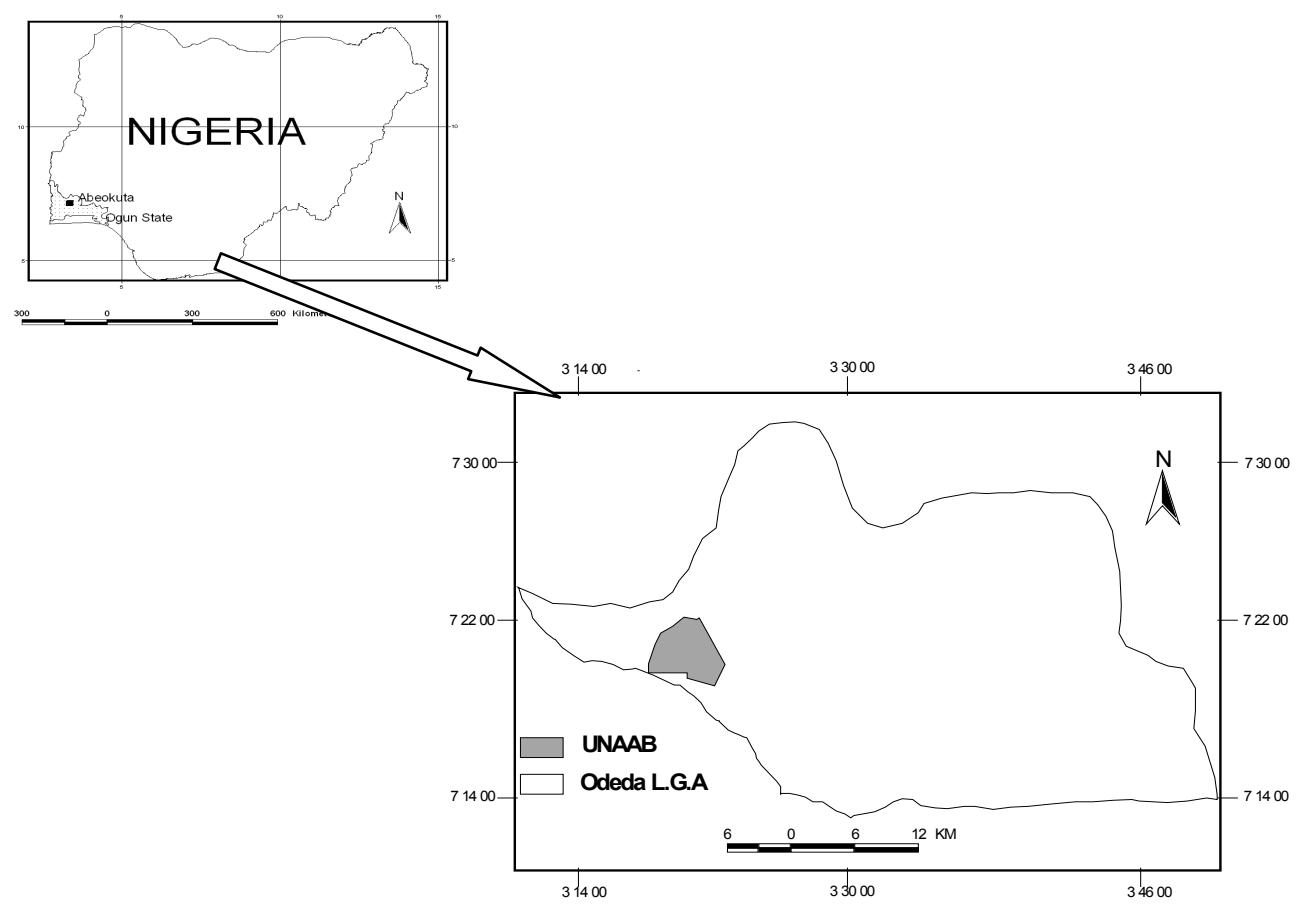

Figture 1. Location of University of Agriculture, Abeokuta within Odeda Local Government Area in Ogun State, Southwestern Nigeria.

\subsection{Experimental Design and Field Measurement}

The experimental site, comprised of a piece of land $(30 \mathrm{x}$ $60 \mathrm{~m}^{2}$ ) had previously carried beans and groundnut intercrop but had been fallowed for over 3 years (from 2004-2006). The site was cleared manually using cutlass in November 2006 , in preparation for the 2007 cropping following the popular practice by the farmers in the study area. This period marks the preparatory period for the cultivation of early yam planting in the study area. Yam mounds were made manually using African hoe during the two experimental years. The mounds were of height $60 \mathrm{~cm}$ and spaced $1.5 \times 1.5 \mathrm{~m}^{2}$ a walk way of $1 \mathrm{~m}$ between adjacent row. The mound tillage system was selected for the study not only because it is the most widely use method in the study area, but also because it improves the soil aeration and hydrothermal conditions for crops emergence, root development, crop growth and yield (Kutugi, 2002).Three local white yam, Dioscorea rotundata cultivars (Efuru, ' $\mathrm{A}_{1}$; Ise-osi ' $\mathrm{A}_{2}$; and Oniyere ' $\mathrm{A}_{3}$ ) were used. The choice of selection was due to the fact that the cultivars were the most important edible yams widely grown by farmers in the University's extension villages around the study area. Grass mulch was applied after planting usually between 6.30-7.30 am when radiation intensity was nil (in otherwords before sunrises, when the Cambell Stokes Sunshine recorder was unable to receive enough radiation to burn the Sunshine recording card). After sprouting, the yams were staked to about $3 \mathrm{~m}$ high and the vines were trained regularly. No fertilizer and insecticide were applied and all plots were regularly hand weeded. Bush rat was controlled by regular clearing of the surroundings of the project site. During each of the phonological stages, daily observation of air and rainfall $(\mathrm{mm})$ were made at meteorological enclosure adjacent to the experimental field. Phonological crop growth parameter and yield characters were also measured. Data collected were subjected to analysis of variance (ANOVA) using GenStat Release 7.2 statistical software (Discovery Edition 3) to evaluate the effects of variety on yam growth and yield. The significant difference of treatment means were determined using least significance difference (LSD) $5 \%$ level of probability[14].

\section{Results}

The effect of variety selection on the growth and development of yam for 2007 and 2008 experimental years is shown on table 1and 2. It was observed that variety does not significantly influenced emergence rate, vine length, stem branches, branch length, number of roots, and root length of yam for both trials. However, variety significantly $(\mathrm{P}<0.05)$ influenced vine diameter, number of leaves of yam and leaf area index, LAI for 2007 and 2008 experimental year. It was also observed that Efuru has the largest number of leaves and LAI followed by Ise-osi, then Oniyere in both experimental years.

The effect of variety selection on the yield and yield components of yam for 2007 and 2008 experimental years is shown on table 3 and 4 . There was no significant difference $(\mathrm{P}>0.05)$ in tuber length, tuber weight, number of tuber and tuber yield of selected yam varieties planted in the study area. However, variety selection significantly influenced tuber diameter of yam influenced tuber diameter of yam particularly in 2008 croping season. 
Table 1. Effect of yam variety on growth and development of three white yams grown at Abeokuta during 2007 cropping season

\begin{tabular}{|c|c|c|c|c|c|c|c|c|c|}
\hline Factor & $\begin{array}{c}\text { Emergence } \\
\%\end{array}$ & $\begin{array}{l}\text { Vine elong } \\
\text { (cm ) }\end{array}$ & $\begin{array}{c}\text { No. of } \\
\text { branches }\end{array}$ & $\begin{array}{l}\text { No. of } \\
\text { leaves }\end{array}$ & $\begin{array}{l}\text { No. of } \\
\text { roots }\end{array}$ & $\begin{array}{l}\text { Vine diameter } \\
(\mathrm{cm})\end{array}$ & $\begin{array}{l}\text { Branch length } \\
(\mathrm{cm})\end{array}$ & $\begin{array}{l}\text { Root length } \\
\text { (cm) }\end{array}$ & LAI \\
\hline Efuru & $41.7 \pm 7.21$ & $83.9 \pm 26.20$ & $20.8 \pm 2.42$ & $499.5 \pm 121.14$ & $21.1 \pm 2.96$ & $1.511 \pm 0.07$ & $71.8 \pm 7.76$ & $31.1 \pm 3.12$ & $1.078 \pm 0.42$ \\
\hline Ise-osi & $44.0 \pm 6.45$ & $74.4 \pm 24.69$ & $15.5 \pm 2.40$ & $571.8 \pm 129.32$ & $21.4 \pm 2.28$ & $1.358 \pm 0.07$ & $65.3 \pm 6.02$ & $29.1 \pm 2.61$ & $0.911 \pm 0.28$ \\
\hline Oniyere & $43.8 \pm 6.93$ & $70.8 \pm 23.83$ & $19.2 \pm 2.61$ & $380.7 \pm 72.89$ & $18.3 \pm 2.63$ & $1.294 \pm 0.04$ & $55.3 \pm 6.29$ & $25.7 \pm 2.93$ & $0.439 \pm 0.12$ \\
\hline$P$ & 0.838 & 0.805 & 0.253 & $<0.001 *$ & 0.637 & $0.026 * *$ & 0.186 & 0.411 & $0.002 *$ \\
\hline
\end{tabular}

*Significant at $\mathrm{P}<0.01 * *$ Significant at $\mathrm{P}<0.05$

Table 2. Effect of yam variety on growth and development of three white yams grown at Abeokuta during 2008 cropping season

\begin{tabular}{|c|c|c|c|c|c|c|c|c|c|}
\hline Factor & $\begin{array}{c}\text { Emergence } \\
\%\end{array}$ & $\begin{array}{l}\text { Vine elong } \\
(\mathrm{cm})\end{array}$ & $\begin{array}{c}\text { No. of } \\
\text { branches }\end{array}$ & $\begin{array}{l}\text { No. of } \\
\text { leaves }\end{array}$ & $\begin{array}{l}\text { No. of } \\
\text { roots }\end{array}$ & $\begin{array}{l}\text { Vine diameter } \\
(\mathrm{cm})\end{array}$ & $\begin{array}{l}\text { Branch length } \\
(\mathrm{cm})\end{array}$ & $\begin{array}{l}\text { Root length } \\
\quad(\mathrm{cm})\end{array}$ & LAI \\
\hline Efuru & $72.2 \pm 6.66$ & $462 \pm 56.75$ & $22.2 \pm 3.17$ & $439.9 \pm 46.6$ & $25.8 \pm 3.19$ & $1.528 \pm 0.07$ & $83.2 \pm 13.23$ & $32.3 \pm 2.92$ & $1.035 \pm 0.21$ \\
\hline Ise-osi & $71.3 \pm 4.78$ & $326 \pm 32.82$ & $21.4 \pm 3.58$ & $484 \pm 85.05$ & $26.8 \pm 3.08$ & $1.369 \pm 0.08$ & $72.8 \pm 7.60$ & $31.1 \pm 2.36$ & $0.917 \pm 0.24$ \\
\hline Oniyere & $70.3 \pm 4.97$ & $319 \pm 26.59$ & $23.2 \pm 3.69$ & $435.2 \pm 46.67$ & $23.7 \pm 3.34$ & $1.322 \pm 0.05$ & $79.0 \pm 7.64$ & $32.2 \pm 3.46$ & $0.823 \pm 0.14$ \\
\hline $\mathrm{P}$ & 0.935 & $<0.001 *$ & 0.927 & $<0.001^{*}$ & 0.808 & 0.059 & 0.746 & 0.956 & 0.061 \\
\hline
\end{tabular}

*Significant at $\mathrm{P}<0.01 * *$ Significant at $\mathrm{P}<0.05$

Table 3. Effect of yam variety on yield and yield characteristic of three white yams grown at Abeokuta during 2007 cropping season

\begin{tabular}{|c|c|c|c|c|c|}
\hline Factor & $\begin{array}{c}\text { Tuber length } \\
(\mathrm{cm})\end{array}$ & $\begin{array}{c}\text { Tuber diameter } \\
(\mathrm{cm})\end{array}$ & $\begin{array}{c}\text { Tuber weight } \\
(\mathrm{kg})\end{array}$ & $\begin{array}{c}\text { No of tuber } \\
\text { Harvest yield } \\
\text { ton/ha }\end{array}$ & $5.38 \pm 1.47$ \\
\hline Efuru & $17.0 \pm 3.81$ & $4.89 \pm 1.05$ & $1.67 \pm 0.37$ & $0.778 \pm 0.24$ & $4.97 \pm 1.03$ \\
\hline Ise-osi & $23.3 \pm 3.87$ & $6.03 \pm 0.98$ & $1.56 \pm 0.31$ & $0.750 \pm 0.12$ & $4.54 \pm 1.39$ \\
\hline Oniyere & $18.8 \pm 4.18$ & $5.41 \pm 1.21$ & $1.54 \pm 0.36$ & $0.556 \pm 0.12$ & 0.214 \\
\hline
\end{tabular}

*Significant at $\mathrm{P}<0.01 * *$ Significant at $\mathrm{P}<0.05$

Table 4. Effect of yam variety on yield and yield characteristic of three white yams grown at Abeokuta during 2008 cropping season

\begin{tabular}{|c|c|c|c|c|c|}
\hline Factor & $\begin{array}{c}\text { Tuber length } \\
(\mathrm{cm})\end{array}$ & $\begin{array}{c}\text { Tuber diameter } \\
(\mathrm{cm})\end{array}$ & $\begin{array}{c}\text { Tuber weight } \\
(\mathrm{kg})\end{array}$ & $\begin{array}{c}\text { No of tuber } \\
\text { Harvest yield } \\
\text { ton/ha }\end{array}$ \\
\hline Efuru & $34 \pm 2.63$ & $10.09 \pm 0.76$ & $3.33 \pm 0.34$ & $1.056 \pm 0.07$ & $11.94 \pm 1.71$ \\
\hline Ise-osi & $34.2 \pm 1.91$ & $12.05 \pm 0.54$ & $3.36 \pm 0.22$ & $1.139 \pm 0.04$ & $11.64 \pm 1.18$ \\
\hline Oniyere & $40.3 \pm 2.00$ & $11.81 \pm 0.59$ & $3.33 \pm 0.25$ & $1.178 \pm 0.04$ & $11.53 \pm 1.40$ \\
\hline & 0.066 & $0.028^{* *}$ & 0.993 & 0.567 & 0.936 \\
\hline
\end{tabular}

*Significant at $\mathrm{P}<0.01 * *$ Significant at $\mathrm{P}<0.05$

\section{Discussion}

The selection of variety is among the factors that contributes to the realization of a successful cropping[1][2][9]. Hence, the fact that the total rainfall (1177.2 and $1201.6 \mathrm{~mm}$ for 2007 and 2008 experimental years respectively) recorded at the study site fell within the range of optimum annual rainfall $(1000-1500 \mathrm{~mm})$ reported for yam growth is not enough criteria for suitable crop variety selection in the study area. For instance if we were to base our assessment only on the total annual rainfall, the present study area would fall within the optimal range for yams cultivars and as such we might assume that no further investigation was meaningful. However, recalling the fact that rainfall in the area is characterized by an unpredictable distribution, variability and seasonality, then if a high total rainfall received is as a result of one or two sporadic downpours, widely separated by periods of dry spells, as experienced in the 2007 experimental year, such rainfall might not contribute meaningfully to crop growth. Usually such downpours often generate flash floods while the little amount of rainfall happens to evaporation rather than effectively recharging the soil for subsequent use by plant. It follows therefore that adequacy for good plant growth does not depend solely on total rainfall but a combination of rainfall and evaporation. Furthermore, temperature varied between $21^{\circ} \mathrm{C}$ and $30.5^{\circ} \mathrm{C}$ in both the 2007 and the 2008 cropping season. This was similar to the temperature range suggested for a good crop growth and yield in Nigeria[11][13].[13] reported a similar range that resulted in a good crop growth and yield in Umudike, East of Nigeria. Since soil and thermal factors are not constraints though the duration of rains is appreciably longer and more reliable in Southwest than elsewhere in Nigeria. It might be possible to develop a cropping pattern that would involve planting early maturity variety in the study area. A selection of yam variety with appropriate phenologies that synchronize the crop growth cycle with the period of effective water availability is required. For instance, it was observed from study that though there were no significant difference in most of the yam growth parameters measured like the emergence rate, vine length, number of stem branches, number of stem roots, branch length, tuber length, tuber diameter, tuber weight, number of tuber and the yield for the different yam variety planted during the 2007 and 2008, there were still some significant difference in some major parameter like the number of leaves, vine diameter and the LAI. It was observed that the Efuru and Ise-osi has the higher 
number of leaves and LAI followed by the Oniyere. This implies that though all selected yam are suitable for planting in the study area. There are still some early maturing and moisture tolerant varieties that could have a larger canopy (LAI) and produce more yield even if the difference.

\section{Conclusions and Recommendations}

From this study, it is obvious that knowledge of climatic conditions can allow us to develop a seasonal management strategy for yam production in Southwest Nigeria. The study revealed that judging from the duration of the period of effective water availability, rainfall during the moist period, extreme lateness of onset of rainfall and water requirement by each of selected yam varieties, the production potential of some variety such as Efuru and Ise-osi can be encouraged in the study area.

\section{REFERENCES}

[1] N.J. Bello. Investigating the optimum planting date for sorghum in the forest savanna transition zone of Nigeria. 1999

[2] N.J. Bello. Application of rainfall- potential evapotranspiration model for the determination of optimum planting date of maize (Zea mays) in a tropical wet and dry climate. 2000

[3] H.J. Critchfield. Climate and Agriculture - In " General climatology". Pretence Hall, Incorporation,England. 221-245pp.1974

[4] U.N. Ekaputa. Agricultural systems. Port Harcourt: UNIK Publishers. pp. 126-134. 2004

[5] T.U. Ferguson and F.A. Gumbs. Effect of soil compaction on leaf numbers and area, and tuber yield of white Lisbon yam.
Proceedings fourth Symposium of International Society for Tropical Root Crops. Cock, J., Maclntyre, R. and Graham, M. eds. CIAT, Cali, Colmbia. IDRC- 080e. 89-93pp. 1976

[6] I.J. Jackson. Climate, Water and Agriculture in the tropic. London: Longman. John Wiley and sons, New York.234 248pp. 1977

[7] A.D. Kutugi. Comparative analysis between indigenous and modern tiilage practices in the production of Dioscorea rotundata and Dioscorea cayenensis in the middle belt of Nigeria. Journal agriculture environment 2(1): 53-66. 2002.

[8] O.G. Obiokoro. Agrometeorology. Onitsha: Dunkwu Publishers. pp. 24-30. 2005

[9] F.O. Olasantan. Effect of population density and sowing date of pumpkin on soil hydrothermal regime, weed control and crop growth in a yam pumpkin intercrop. Experimental Agriculture 43: 365-380. 2007

[10] J.E. Oliver. "Cli mate and man's environment". John Wiley and sons, Incorpoated, New York. 517pp. 1972

[11] I.C. Onwueme. The sprouting process in yam (Dioscorea spp) tuber pieces. Journal of Agriculture Science (Cambridge) 81: 375-379. 1973

[12] G.C. Orkwor and I.J. Ekanayake. Growth and Development. In: The progress in yam Research. G.C.Orkwor, R. Asiedu and I.J. Ekanayake, eds.IITA, Ibadan, Nigeria. 39 62pp. 1998

[13] G.C.Orkwor. Studies on the critical period of weed interference in yam intercropped with maize (Zea $\backslash$ mays L.), Okra (Abelinoschus esculentus L. Moench), Sweet potato and the biology of associated weeds. Ph.D thesis. University of Nigeria, Nsukka, Nigeria. 262pp. 1990

[14] R.G.B. Steel and J.H. Torrie. Principle and procedures of statistics, M cGraw - Hill Book Co., New York, U.S. 633PP. 1988

[15] P. Vernier and P. Dansi. Participatory assessment and farmers' knowledge on yam varieties (D. rotunda and D. cayenensis) in Benin. Paper presented at the ISTRC 2000 symposium, Tsukuba, Ibaraki, Japan, Sept. 10-16 2000. pp. 1-17. 2000 